\title{
Longitudinal manganese and copper balances in young infants and preterm infants fed on breast-milk and adapted cow's milk formulas
}

\author{
BY KLAUS DÖRNER, STEFAN DZIADZKA, ANDREAS HÖHN, \\ ERIKA SIEVERS, HANS-DIETER OLDIGS, GISELA SCHULZ-LELL \\ AND JÜRGEN SCHAUB
}

University Children's Hospital, D 2300 Kiel 1, Federal Republic of Germany

(Received 14 July 1988 - Accepted 20 December 1988)

\begin{abstract}
1. $\mathrm{Mn}$ and $\mathrm{Cu}$ intake and retention in twenty full-term infants and six preterm infants were studied on the basis of $72 \mathrm{~h}$ balances. The age of the infants was $2-16$ weeks and the gestational age of the preterm infants (triplets) 34 and 36 weeks. Three nutrition schemes were pursued: breast-fed, formula-fed with unsupplemented adapted formula and formula-fed with trace element supplementation.

2. The mean $\mathrm{Mn}$ concentration of all breast-milk samples ( $n 2339$ ) was $6.2 \mu \mathrm{g} / 1$. The two formulas had similar Mn concentrations $(77$ and $99 \mu \mathrm{g} / \mathrm{l})$ but had different $\mathrm{Fe}, \mathrm{Cu}(121$ and $619 \mu \mathrm{g} / \mathrm{l}), \mathrm{Zn}$ and $\mathrm{I}$ contents. The mean $\mathrm{Cu}$ concentration in mother's milk was $833 \mu \mathrm{g} / \mathrm{l}$.

3. The following mean daily $\mathrm{Mn}$ intakes and retentions $(\mu \mathrm{g} / \mathrm{kg})$ respectively were measured: breast-fed fullterm 1.06 (SD 0.43 ) and 0.43 (SD 0.65), formula-fed full-term 14.2 (SD 3.1) and 2.8 (SD 4.8), formula-fed preterm 15.0 (SD 2.2) and 0.06 (SD 5.87). The results for $\mathrm{Cu}$ were 114.5 (SD 22.3) and 88.0 (SD 46.5) $\mu \mathrm{g} / \mathrm{kg}$ in breast-fed, 19.8 (SD 4.2) and $4 \cdot 6(-11 \cdot 5-9 \cdot 6)$ in the unsupplemented formula-fed and 106.4 (SD 18.9) and 55.5 (SD 20.3) in the supplemented formula full-term infant group. No significant influence of the trace element contents of the formulas on the relative retention of $\mathrm{Mn}$ or $\mathrm{Cu}$ was found.

4. Young preterm infants, and to some degree young full-term infants, often had negative Mn balances caused by a high faccal excretion. The formulas with a $\mathrm{Mn}$ concentration below $100 \mathrm{\mu g} / 1$ gave a sufficient supply of $\mathrm{Mn}$. Preterm infants fed on the unsupplemented formula had a marginal $\mathrm{Cu}$ supply and their first balances were negative $(-3.8(\mathrm{SD} 1.8) \mu \mathrm{g} / \mathrm{kg})$.

5. In accordance with the estimated safe and adequate daily dietary intakes (recommended dietary allowances), formula-fed infants receive much more $\mathrm{Mn}$ than breast-fed infants and their absolute retention is higher.

6. $\mathrm{Cu}$ from breast-milk had a significantly better biological availability than that from cow's milk formula. If retentions similar to those in breast-fed infants are intended, we conclude, therefore, that cow's milk formula should be fortified with $\mathrm{Cu}$ up to a level of at least $600 \mu \mathrm{g} / \mathrm{l}$.
\end{abstract}

The biological relevance of $\mathrm{Mn}$ was noted in poultry and rats showing defective calcification of the otoliths (resulting in ataxia) and the skeleton and other defects based on a depressed mucopolysaccharide synthesis (Hurley, 1985). Furthermore, Mn-deficient rats have second-generation offspring which show an abnormal glucose tolerance test, possibly caused by decreased insulin output (Hurley, 1985). Mn deficiency in man has been observed only once in a patient under parenteral nutrition (Doisy, 1974). He suffered from a prolonged prothrombin clotting time. In newborns and infants no symptoms of deficiency have yet been identified. The vitamin K-dependent coagulopathy in breast-fed infants, however, could be hypothetically connected to $\mathrm{Mn}$ deficiency by low $\mathrm{Mn}$ intake in these children. At this age it should be relatively easy to diagnose a deficiency, as body-weightrelated increase of tissues and the need for nutrients are highest during infancy. Chondrocytes are very active (glycosaminoglycan synthesis in bone and connective tissue) here and the Mn-dependent enzyme superoxide dismutase (EC 1.15.1.1; mitochondrial form) is important for those newborns receiving oxygen therapy (Pleban et al. 1985). Preterms may be especially vulnerable to an insufficient Mn supply because of their need for catch-up growth and because the fetal liver does not accumulate $\mathrm{Mn}$ (in contrast to $\mathrm{Cu}$ ) (Widdowson et al. 1972).

Our interest in studying the Mn metabolism in young infants arose from the fact that we noticed a distinct discrepancy between the very low Mn contents of breast-milk and the 
recommended dietary allowances (RDAs; National Research Council, 1980) for Mn intake of infants. The values differed by a factor of 100 . As there have been few balanced studies reported we decided to compare $\mathrm{Mn}$ intake and retention of term and preterm infants fed on either breast-milk or milk formulas. Furthermore we examined the often quoted assumption that $\mathrm{Mn}$ absorption is influenced by the varying iron concentrations found in milk formulas.

Nutritional $\mathrm{Cu}$ deficiencies have been described in premature born and in malnourished infants (Al-Rashid \& Spangler, 1971; Ashkenazi et al. 1973; Graham \& Cordano, 1976; Heller et al. 1978; Tanaka et al. 1980; Naveh et al. 1981 ; Levy et al. 1985). During the third trimester of pregnancy the fetal liver accumulates two-thirds of the total $\mathrm{Cu}$ in the body (Shaw, 1980). Preterm infants cannot store these amounts of $\mathrm{Cu}$ and are therefore especially sensitive to an alimentary undersupply of $\mathrm{Cu}$. From the existing literature it has not been clearly shown whether low $\mathrm{Cu}$ intakes in young infants, as cited previously, are the main and exclusive causes of deficiency symptoms. Hillmann et al. (1981) and recently Tyrala (1986) found that $\mathrm{Cu}$ retention from milk and $\mathrm{Cu}$ serum level are independent of the formula's $\mathrm{Cu}$ content. This finding has to be re-evaluated, because the estimated safe and adequate daily dietary intakes (RDAs; National Research Council, 1980) are as high as 100 $\mu \mathrm{g} \mathrm{Cu} / \mathrm{kg}$ compared with a generally accepted breast-milk intake of below $50 \mu \mathrm{g} / \mathrm{kg}$ at the age of $2-4$ months. Also, our knowledge about the bioavailability of $\mathrm{Cu}$ from formulas or breast-milk is meagre.

Metabolic balance studies are regarded as a valuable approach for answering the following questions, assuming an increasing need of the growing organism (Beisel, 1979).

(1) How do intake and retention of $\mathrm{Mn}$ and $\mathrm{Cu}$ from breast-milk compare with those from milk formulas (supplemented with or without trace elements)?

(2) Are the metabolic balances in preterm infants comparable with those in full-term infants?

(3) Does high Fe intake by formula or by additional medication influence the availability of $\mathrm{Mn}$ or $\mathrm{Cu}$ ?

(4) Are the RDAs in accordance with breast-milk nutrition?

\section{MATERIALS AND METHODS}

\section{Subjects}

Five groups of male infants were studied (Table 1): (1) eleven breast-fed full-term (BT); (2) four full-term, given a commercially available adapted milk formula (FT); (3) five fullterm, given a similar formula containing essentially the same Mn content but supplemented with $\mathrm{Fe}, \mathrm{Cu}, \mathrm{Zn}$ and I (SFT); (4) three preterm (triplets) with a gestational age of 34 weeks, given the unsupplemented formula (FP); (5) three preterm (triplets) with a gestational age of 36 weeks, given the supplemented formula (SFP). The liquid formulas (cow's-milk-based Preaptamil ${ }^{\circledR}$; Milupa AG, Friedrichsdorf) contained $(\mathrm{g} / \mathrm{l}): 15$ protein, 36 fat, 72 carbohydrate, $2800 \mathrm{~kJ}(670 \mathrm{kcal}) / 1$ and trace elements as shown in Table 2.

Supplementation was factory-made by addition (/l) of $57 \mathrm{mg} \mathrm{FeSO}_{4} .7 \mathrm{H}_{2} \mathrm{O}, 11 \mathrm{mg}$ $\mathrm{CuSO}_{4} .5 \mathrm{H}_{2} \mathrm{O}$ and $9 \mathrm{mg} \mathrm{ZnSO} \mathrm{Zn}_{4} .7 \mathrm{H}_{2} \mathrm{O}$. In a child of group FT an $\alpha_{1}$-antitrypsin deficiency (type $\mathrm{Pi} \mathrm{ZZ}$ ) was detected towards the end of the study. As his balances were within the range of the other results, he was not removed from the study. All others were apparently healthy.

A total of thirty-eight children initially participated in the study. The balances could not be performed correctly on eleven of them because of technical problems, e.g. unmeasured loss of urine, soreness of the anogenital region, unmeasured or mixed intake (breast-milk and formula milk) or refusal of the mothers to continue balancing. For similar reasons the intended five balances per infant could not always be achieved. 
Table 1. Details of infants participating in the study

(Mean values and one standard deviation)

\begin{tabular}{|c|c|c|c|c|c|c|c|c|c|c|}
\hline \multirow[t]{2}{*}{ Group... } & \multicolumn{2}{|c|}{ BT } & \multicolumn{2}{|c|}{ FT } & \multicolumn{2}{|c|}{ SFT } & \multicolumn{2}{|c|}{ FP } & \multicolumn{2}{|c|}{ SFP } \\
\hline & Mean & SD & Mean & SD & Mean & SD & Mean & SD & Mean & SD \\
\hline \multicolumn{11}{|l|}{ Wt (kg): } \\
\hline First collection period & $4 \cdot 1$ & $0-4$ & $3 \cdot 3$ & 0.7 & $3 \cdot 4$ & $0 \cdot 2$ & $1 \cdot 8$ & $0 \cdot 3$ & $2 \cdot 3$ & $0 \cdot 2$ \\
\hline Fifth collection period & 6.7 & $0 \cdot 7$ & $6 \cdot 2$ & 0.8 & 6.6 & $0 . \overline{8}$ & $2 \cdot 2^{*}$ & 0.5 & $5 \cdot 2$ & $0 \cdot 3$ \\
\hline No. of children & \multicolumn{2}{|c|}{11} & \multicolumn{2}{|c|}{$4(3)$} & \multicolumn{2}{|c|}{5} & \multicolumn{2}{|c|}{3} & \multicolumn{2}{|c|}{3} \\
\hline No. of collection periods & \multicolumn{2}{|c|}{44} & \multicolumn{2}{|c|}{15} & \multicolumn{2}{|c|}{10} & \multicolumn{2}{|c|}{6} & \multicolumn{2}{|c|}{15} \\
\hline
\end{tabular}

BT, Breast-fed full-term; FT, full-term given unsupplemented, adapted cow's-milk formula; SFT, full-term given supplemented formula (additional iron, copper and zinc as sulphates); FP, preterm triplets given unsupplemented formula; SFP, preterm triplets given supplemented formula.

* Group studied only in the first and second collection period.

Table 2. Mean concentrations of trace elements $(\mu \mathrm{g} / l)$ in the three types of milk given, as determined by long-term analysis

\begin{tabular}{lccc}
\hline \hline & Breast-milk* & $\begin{array}{c}\text { Unsupplemented } \\
\text { formula }\end{array}$ & $\begin{array}{c}\text { Supplemented } \\
\text { formula } \uparrow\end{array}$ \\
\hline Copper & 833 & 121 & 619 \\
Zinc & 2062 & 1260 & 3880 \\
Iron & 429 & 1124 & 10080 \\
Manganese & 6.2 & $98 \cdot 6$ & 77.0 \\
\hline \hline
\end{tabular}

* Depending on stage of lactation.

$\dagger \mathrm{Cu}, \mathrm{Zn}$ and $\mathrm{Fe}$ were supplemented as sulphates.

\section{Balance periods and intakes}

Five $72 \mathrm{~h}$ collection periods were intended for each infant participating in the study, beginning at the ages of $2,5,8,12$ and 16 weeks. The dates differed slightly in individual cases. In most infants all five collection periods were completed. In some infants, however, single balances had to be discarded because of additional intakes, like carrot baby food, or because of collection problems. For the balances, steady-state conditions were assumed. The beginning and end of the $3 \mathrm{~d}$ were marked by carmine red which contained negligible amounts of trace elements.

Intake by breast-milk was measured by test-weighing; the intake of formula was read from the bottles. Thirteen incidents of regurgitation (at thirteen collection days of nine different children) of more than approximately $15 \mathrm{ml}$ milk were assessed. The loss of milk was (although not measured) obviously low, because the corresponding balances were normal in comparison with the other balances of the same child. Regurgitation of less than approximately $15 \mathrm{ml}$ was regarded as negligible, as this quantity is less than $3 \%$ of the total intake and within the overall experimental error.

In a few cases tea was given in addition to milk. The Mn concentrations in these samples was measured and the intake was calculated and added. In two balances of group BT and in four balances of group FT small amounts of additional fluid (tea) were given without retaining samples for the laboratory. The balance error by this additional intake was low in these cases and regarded as negligible. In seven balances of group FT, in two balances of group SFT and in nine balances of group SFP additional Fe medication (approximately $18 \mathrm{mg} / \mathrm{d}$ ) was prescribed by the family doctors. 


\section{Collection of breast-milk, urine and faeces}

The collection of materials was performed at home (preterms: partly at the hospital). To achieve and check on the completeness of collected materials, the following measures were taken.

(1) Only selected, motivated mothers participated in the study.

(2) Oral and written explanations were given to the mothers.

(3) Practical instructions were given to the mothers followed by daily supervision by one of us (E.S.).

(4) Completeness of urine collection was easily controlled by the solid adhesion of the urine bags and the dryness of the nappies. In those cases of intermediately loosened urine bags, the nappies were collected and weighed for estimation of urine loss. This amount was taken into account in the calculation.

(5) Plausibility control of intake and excretion measurements was achieved by intra- and inter-individual comparisons of daily intake and excretion, by the feeding and defaecation intervals recorded by the mothers and by regression analysis of the day-to-day renal excretions.

In each suckling procedure, milk samples $(2-5 \mathrm{ml})$ were taken before and after feeding from each breast, resulting in a maximum of four milk samples for each suckling during the collection periods.

Urine samples were collected in 24-h portions using urine bags with a drainage facility. Reliable fixing of the bags was achieved by a special acrylate adhesive. In those cases where the bag came off before the 72 nd hour, the nappies were weighed to estimate the urine volume lost. Weight losses by evaporation were regarded as unimportant : renal $\mathrm{Mn}$ and $\mathrm{Cu}$ excretion is very small compared with faecal excretion. Faeces were gathered on traceelement-free nappy inlayers according to the appearance of the carmine marker given with the feed at 0 and $72 \mathrm{~h}$. The sample with the first red marking initialized the stool collection, the second red sample terminated collection and was excluded from the sampling.

All samples were collected with plastic materials free of trace-element contamination as determined by random tests.

\section{Analytical methods}

Milk samples and faeces were lyophilized, ashed under pressure with nitric acid in a polytetrafluoroethylene (PTFE) system according to Tölg (Kotz et al. 1972) at $180^{\circ}$, evaporated and the dry residue dissolved with high-purity water. Urine samples were analysed without pretreatment. Measurements were performed by atomic absorption spectrometry (AAS) with a graphite furnace and partly by flame atomic absorption spectrometry under standard conditions. For precision controls the two formulas given were used, replacing every tenth breast-milk sample. These results, together with the other precision and accuracy controls and addition assays have been published elsewhere (Dörner et al. 1985). Typical serial precision was 5\%, day-to-day precision $11-14 \%$ (formulas) and recovery rates $87.9-108 \%$ (breast-milk). Addition assays and reference materials (bovine liver, National Bureau of Standards, Washington DC; and milk powder, International Atomic Energy Agency, Vienna) gave results within the limits of confidence $(2 \mathrm{SD})$.

\section{Statistical methods}

Results are given as arithmetic means and standard deviations (partly including inter- and intra-individual variations), if the values were normally distributed. Otherwise median and percentiles are given and the non-parametric U-test (Wilcoxon, Mann, Whitney) was used. 
RESULTS

Intake and absolute retentions for breast-fed infants

$\mathrm{Mn}$. A total of 2339 milk samples was analysed for $\mathrm{Mn}$ concentration. The median was $6.2 \mu \mathrm{g} / \mathrm{l}$, the $80 \%$ range $3.0-14.2 \mu \mathrm{g} / \mathrm{l}$ and the $95 \%$ range $1.8-23.0 \mu \mathrm{g} / \mathrm{l}$. A small but statistically significant increase was found in the course of suckling procedure $(5 \cdot 8-$ $6.6 \mu \mathrm{g} / 1)$, but there was no difference between left and right breast. From the first to the fifth collection period, no consistent or biologically relevant change in $\mathrm{Mn}$ concentration was found.

Mean $\mathrm{Mn}$ intake of breast-fed infants changed little during the five collection periods. Table 3 shows that the intake was highest during the second period and fell continuously later. The arithmetic mean of all fifty-four balances was 1.06 (SD 0.43 ) $\mu \mathrm{g} \mathrm{Mn} / \mathrm{kg}$ per d. The absolute retention in the same group was scattered considerably on the basis of an inconsistent faecal $\mathrm{Mn}$ excretion. The daily mean was 0.43 (SD 0.65 ) $\mu \mathrm{g} \mathrm{Mn} / \mathrm{kg}$. Of fortyfive balances nine were negative. One of them coincided with an infection and two with an additional, partly unmeasured tea intake.

$\mathrm{Cu}$. Concentrations of $\mathrm{Cu}$ in fore- and hind-milk samples are given in Table 4 from the first to the fifth collection period. The medians show a statistically significant $(P<0.001)$ decrease from the first to the fourth collection period and a slight increase thereafter. Individual differences existed: one mother gave milk samples where all concentrations were below $500 \mu \mathrm{g} / \mathrm{l}$, whereas in two others values were always higher than $1000 \mu \mathrm{g} / 1$. During a single nursing procedure $\mathrm{Cu}$ concentration increased (Wilcoxon test with paired values: $P \leqslant 0.05$ ).

The mean daily $\mathrm{Cu}$ intake of breast-fed infants from forty-four balances as 114.5 (SD $22 \cdot 3$ ) $\mu \mathrm{g} / \mathrm{kg}$, based on daily milk volumes ingested of $669-810 \mathrm{ml}$. The results and standard deviations for the different collection periods describe the inter-individual variations. Table 5 shows the intra-individual variation of intake and retention. A calculation of intra-individual coefficients of variation was not performed because of the small number of periods studied in each child.

In the course of the study the intake showed a falling tendency caused by the decreasing $\mathrm{Cu}$ concentration in breast-milk from the first to the fourth collection period (Table 4). The main excretion path of $\mathrm{Cu}$ is faeces; urine contributes only a few percent (mean $6.4 \%$ ). The mean daily faecal excretion was highest in the first collection period $(32.1 \mu \mathrm{g} / \mathrm{kg}$, range 4.4-69.6) and lowest in the fourth collection period (13.1 $\mu \mathrm{g} / \mathrm{kg}$, range $1 \cdot 8-28 \cdot 9)$. Intake and renal plus faecal excretion are shown in Fig. 1. The length of the line between intake and renal plus faecal excretion describes the retention which was highest in the first collection period $(130 \cdot 2$ (SD 52.9) $\mu \mathrm{g} / \mathrm{kg}$ ) and lowest in the fifth collection period (64.0 (range $9 \cdot 2-134 \cdot 0) \mu \mathrm{g} / \mathrm{kg}$ ). It is calculated from the difference between intake and excretion. The mean absolute retention was $88.0(\mathrm{SD} 46.5) \mu \mathrm{g} / \mathrm{kg}$. All balances were positive with one single exception, where the infant had low-grade pyrexia.

\section{Intake and absolute retentions of formula-fed full-term and preterm infants}

$M n$. The formula-fed infants could be divided into two groups differing mainly in the molar $\mathrm{Fe}: \mathrm{Mn}$ quotient: eleven in the unsupplemented-formula group FT and 129 in the supplemented-formula group SFT (for comparison in breast-milk: 68). There was no statistically significant difference between groups in retention. Daily means of the combined five collection periods are summarized in Table 6.

The mean daily retention during the first collection period was highest $(5 \cdot 8$ (SD $5 \cdot 7) \mu \mathrm{g} / \mathrm{kg}$ ).

Of thirty-nine balances eleven were negative.

Preterm infants were fed similarly on the formulas mentioned previously. Results are 
Table 3. Daily manganese intake and retention of breast-fed infants in collection periods $1-5$

(Mean values and standard deviations)

\begin{tabular}{|c|c|c|c|c|c|c|c|c|c|c|c|c|}
\hline \multirow{2}{*}{$\begin{array}{l}\text { Collection period } \\
\text { (no. of balances). }\end{array}$} & \multicolumn{2}{|c|}{$1(7)$} & \multicolumn{2}{|c|}{$2(11)$} & \multicolumn{2}{|c|}{$3(9)$} & \multicolumn{2}{|c|}{$4(9)$} & \multicolumn{2}{|c|}{$5(9)$} & \multicolumn{2}{|c|}{ all (45) } \\
\hline & Mean & SD & Mean & SD & Mean & SD & Mean & SD & Mean & SD & Mean & SD \\
\hline Daily intake $(\mu \mathrm{g} / \mathrm{kg})$ & $1 \cdot 14$ & $0 \cdot 33$ & $1 \cdot 34$ & $0 \cdot 49$ & $1 \cdot 12$ & 0.40 & 0.92 & $0 \cdot 42$ & 0.74 & $0 \cdot 20$ & 1.06 & 0.43 \\
\hline Daily retention $(\mu \mathrm{g} / \mathrm{kg})$ & $0 \cdot 14$ & 0.47 & 0.50 & 0.75 & 0.55 & 0.99 & 0.61 & 0.44 & 0.27 & 0.37 & 0.43 & 0.65 \\
\hline
\end{tabular}

Table 4. Copper concentration in breast-milk (fore- and hind-milk) depending on stage of lactation

(Mean and $80 \%$ range expressed in $\mu \mathrm{g} / 1$; no. of samples given in parentheses)

\begin{tabular}{|c|c|c|c|c|c|c|c|}
\hline $\begin{array}{l}\text { Collection period... } \\
\text { Milk }\end{array}$ & $(n)$ & & 1 & 2 & 3 & 4 & 5 \\
\hline Fore-milk & $(1220)$ & Mean & $1084(266)$ & $960(289)$ & $696(228)$ & $580(206)$ & $680(231)$ \\
\hline Hind-milk & (1121) & $\begin{array}{l}\text { Range } \\
\text { Mean }\end{array}$ & $\begin{array}{r}752-1488 \\
1144(227)\end{array}$ & $\begin{array}{r}608-1416 \\
1040(253)\end{array}$ & $\begin{array}{l}400-1336 \\
720(218)\end{array}$ & $\begin{array}{l}416-984 \\
639(200)\end{array}$ & $\begin{array}{c}395-1156 \\
720(223)\end{array}$ \\
\hline & & Range & $800-1520$ & $624-1650$ & $424-1488$ & $440-1136$ & $416-1200$ \\
\hline
\end{tabular}

given in Table 7. Compared with the full-term infants the intake was similar, but retention in group SFP and the combined preterm infants was strikingly lower, especially in the first collection period. Of the total of balances, ten were negative; this was found in four of six balances of the first collection period.

$C u$. Daily $\mathrm{Cu}$ intake from supplemented cow's-milk formula was 106.4 (SD 18.9) $\mu \mathrm{g} / \mathrm{kg}$. The mean milk uptake was 518 in the first and $995 \mathrm{ml}$ in the last collection period. The daily faecal excretion was $49 \cdot 1$ (SD 19.2) $\mu \mathrm{g} / \mathrm{kg}$. Daily retention ranged from $46 \cdot 6$ (SD 18.9) $\mu \mathrm{g} / \mathrm{kg}$ in the fifth collection period to $64.8(12 \cdot 2-99 \cdot 0) \mu \mathrm{g} / \mathrm{kg}$ in the first collection period. The mean of all balances in this group was 55.5 (SD 20.3) $\mu \mathrm{g} / \mathrm{kg}$; all were positive.

Whereas $\mathrm{Cu}$ balances of the first two groups were comparable, daily intake, faecal excretion and retention in the infants given unfortified adapted milk formula were lower; the means were $19.8(\mathrm{SD} 4 \cdot 2), 12.3(6.0-33.3)$ and $4.6(-11.5-9.6) \mu \mathrm{g} / \mathrm{kg}$ respectively. The renal excretion in this group in relation to the faecal excretion was higher than in the other groups. Of fifteen balances three were negative.

The values for preterm infants are shown in Fig. 2, together with the values of the fullterm infants for comparison. In the supplemented formula group (mean daily retention $51 \cdot 1$ (SD 20.3) $\mu \mathrm{g} / \mathrm{kg}$ ) no significant difference was found, but in the first collection period of the preterm infants given unsupplemented formula all three infants had negative balances $(-1.8,-5.3$ and $-4.0 \mu \mathrm{g} / \mathrm{kg}$ ). This was caused by (relative to the full-term group) high faecal $\mathrm{Cu}$ excretion. In the second collection period their daily retention was $5 \cdot 0(\mathrm{sD} 2 \cdot 3) \mu \mathrm{g} / \mathrm{kg}$.

\section{Relative retentions of $\mathrm{Mn}$ and $\mathrm{Cu}$}

From the absolute $\mathrm{Mn}$ intake and retention, the apparent relative retention (\% of intake) can be calculated. If negative retentions were included, the following means ( $\%$ of intake) were obtained: breast-fed $36 \cdot 7$, full-term infants of group FT $16 \cdot 3$, full-term infants of group SFT $21 \cdot 0$, preterm infants of group FP $9 \cdot 0$, preterm infants of group SFP $5 \cdot 1$. The 
$M n$ and $\mathrm{Cu}$ balances in infants

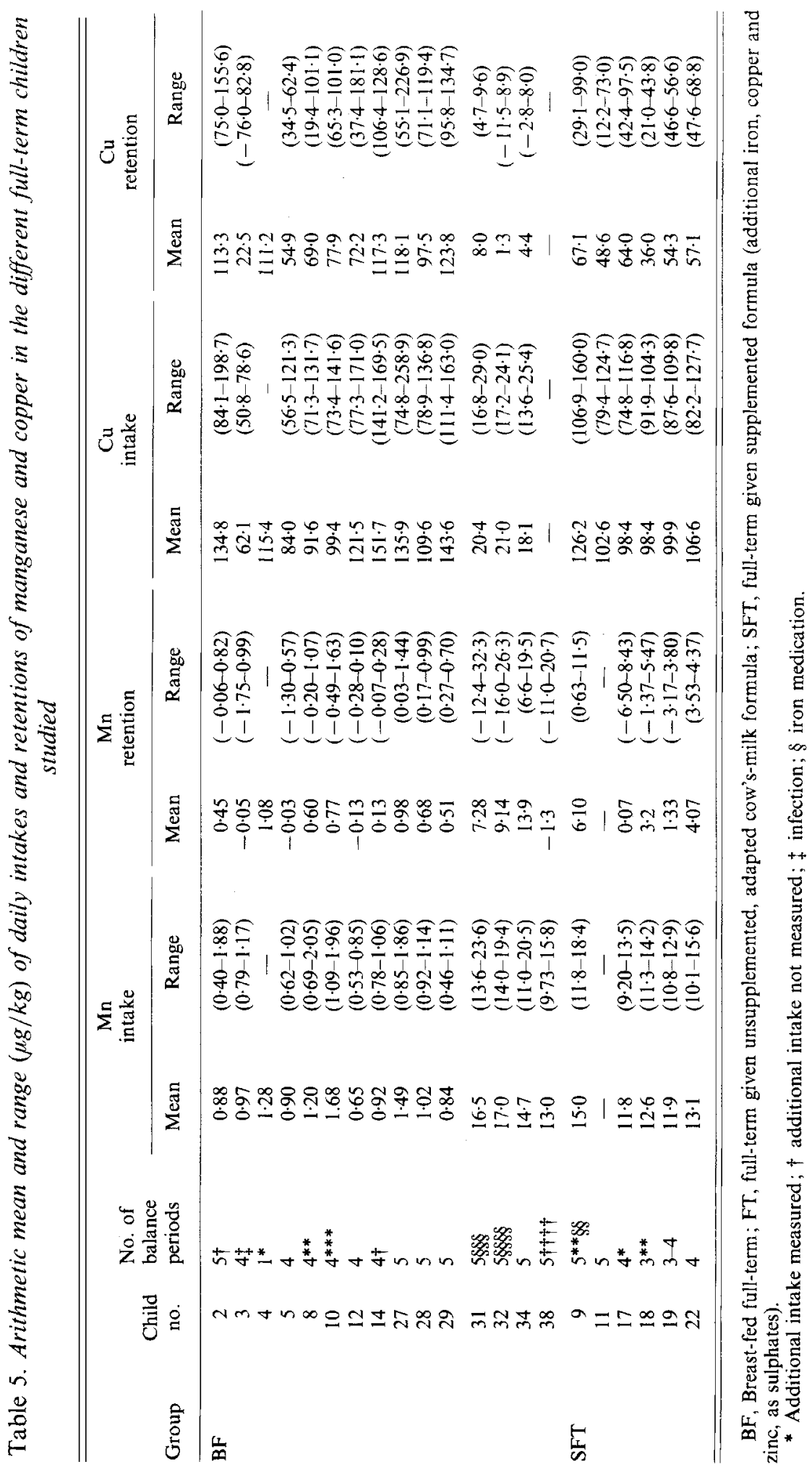




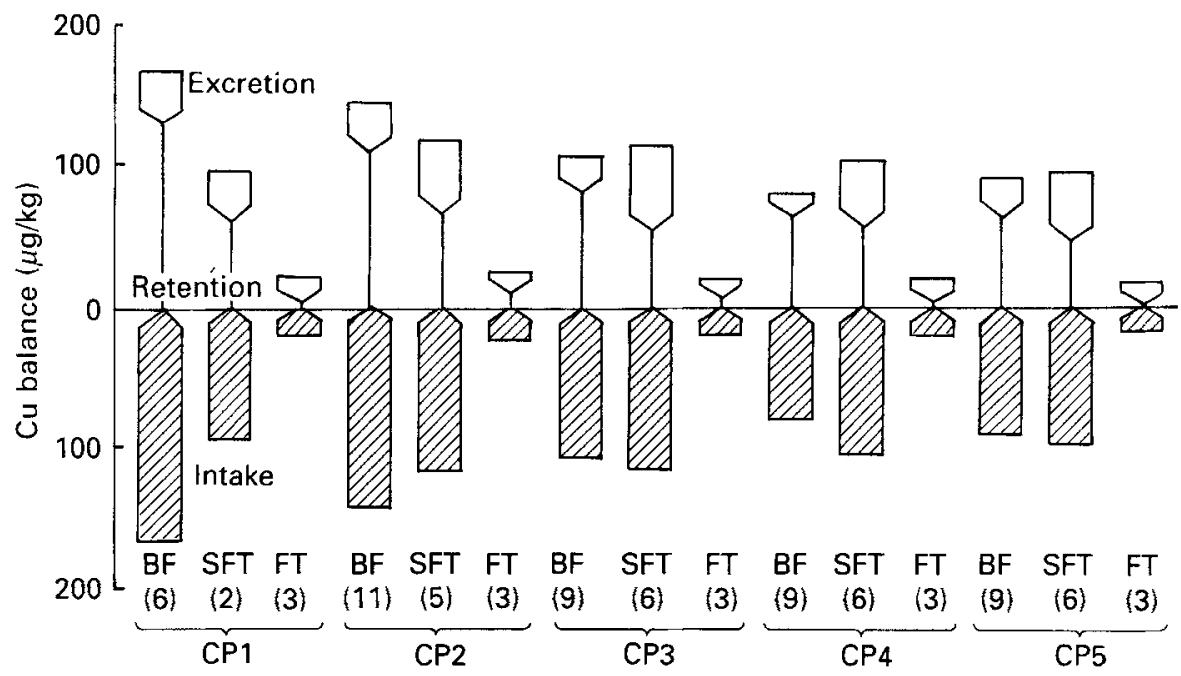

Fig. 1. Copper balances of full-term infants given breast-milk (BF), supplemented cow's-milk formula (SFT) or unsupplemented formula (FT). ( $\square$ ), Excretion; (国) intake; ( - ), retention; the number of balances is given in parentheses. CP, collection period.

Table 6. Daily manganese intake and retention of formula-fed full-term infants during the five collection periods when they were given unsupplemented formula (group FT) or formula supplemented with iron, copper, zinc and iodine (group SFT)

(Mean values and standard deviations)

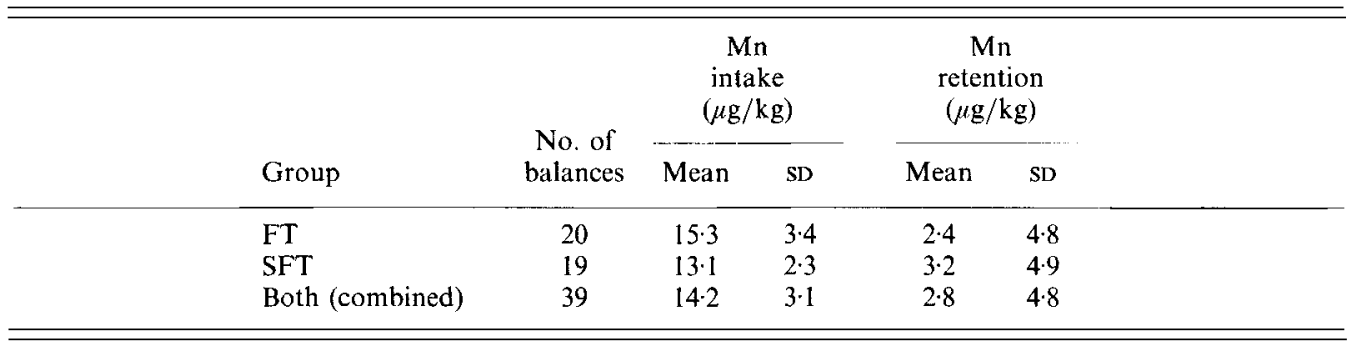

Table 7. Daily manganese intake and retention of formula-fed preterm infants when they were given unsupplemented formula (group FP) or formula supplemented with iron, copper, zinc and iodine (group SFP)

(Group FP was studied only in the first and second collection periods, group SFP during five collection periods. Mean values and standard deviations)

\begin{tabular}{|c|c|c|c|c|c|}
\hline \multirow[b]{2}{*}{ Group } & \multirow{2}{*}{$\begin{array}{c}\text { No. of } \\
\text { balances }\end{array}$} & \multicolumn{2}{|c|}{$\begin{array}{c}\mathrm{Mn} \\
\text { intake } \\
(\mu \mathrm{g} / \mathrm{kg})\end{array}$} & \multicolumn{2}{|c|}{$\begin{array}{c}\mathrm{Mn} \\
\text { retention } \\
(\mu \mathrm{g} / \mathrm{kg})\end{array}$} \\
\hline & & Mean & SD & Mean & SD \\
\hline $\mathrm{FP}$ & 6 & $17 \cdot 4$ & $0 \cdot 3$ & 1.74 & $3 \cdot 20$ \\
\hline SFP & 15 & $14 \cdot 0$ & $1 \cdot 7$ & -0.62 & 6.63 \\
\hline Both (combined) & 21 & $15 \cdot 0$ & $2 \cdot 2$ & 0.06 & 5.87 \\
\hline
\end{tabular}




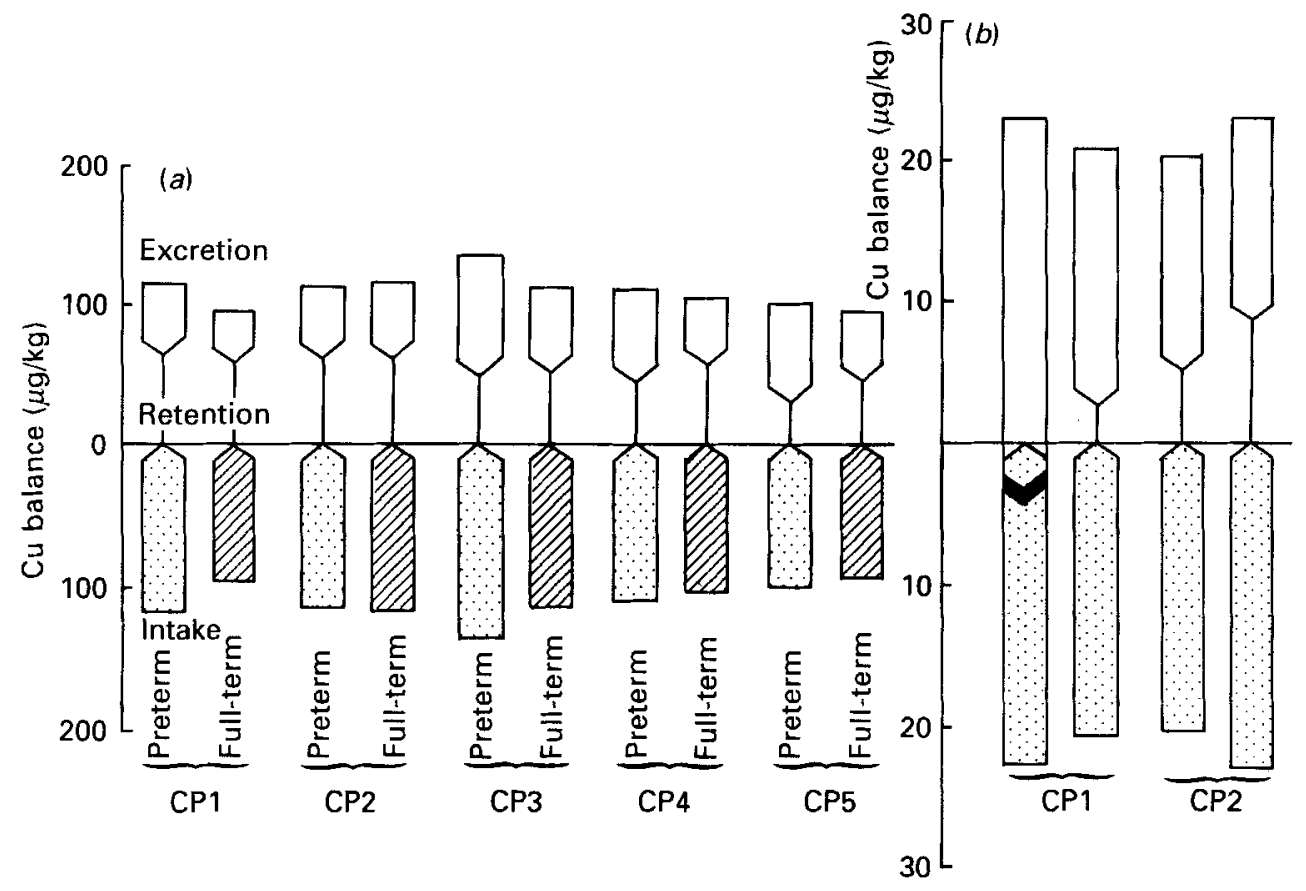

Fig. 2. Copper balances of preterm (圆) infants and appropriate full-term (面) infants given (a) supplemented cow's-milk formula or (b) unsupplemented formula. ( $\square$ ), Excretion; (圈) and (落) intake; $(-)$, retention. Note the scale for $(b)$ is 10 times larger than that for $(a)$. CP, collection period.

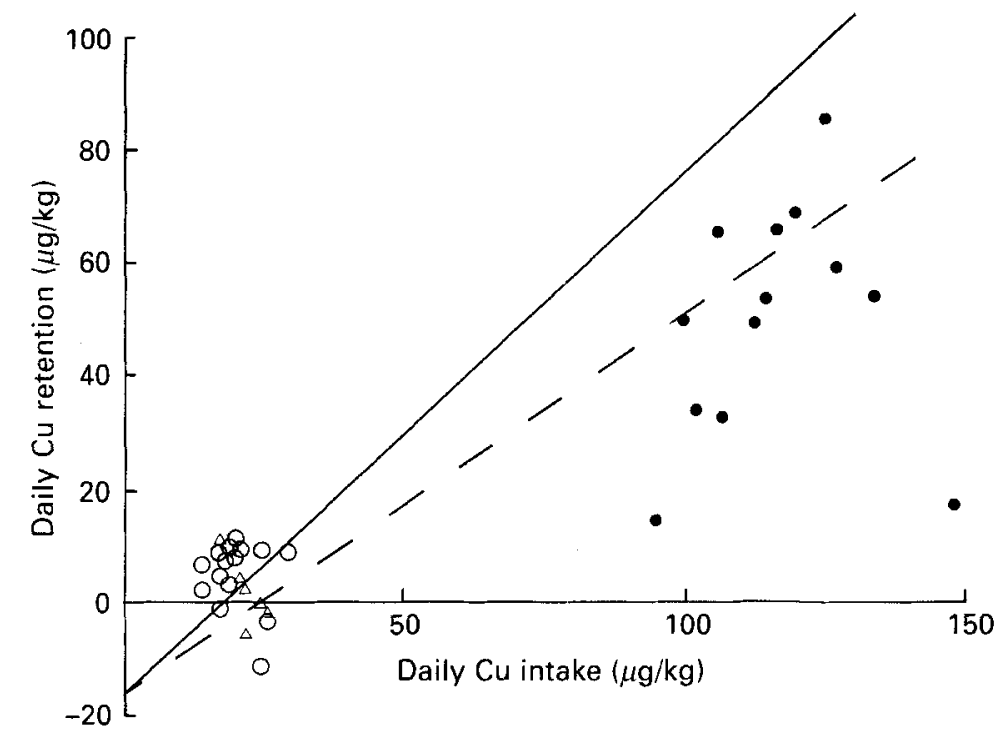

Fig. 3. Relation between copper retention and $\mathrm{Cu}$ intake. For the group of breast-fed infants and the group of supplemented formula-fed full-term infants the linear regression may be calculated. Breast-fed (-):

$$
f(x)=0.920 x-16 \cdot 8, \quad r 0 \cdot 88, n 44 .
$$

Supplemented formula-fed full-term $(--)$ :

$$
f(x)=0 \cdot 676 x-16 \cdot 3, \quad r 0 \cdot 63, n 25 .
$$

The results of the remaining groups are given as: (O) supplemented formula-fed preterm infants, $(O)$ non-supplemented formula-fed full-term infants, $(\Delta)$ non-supplemented formula-fed preterm infants. 
relative retention from breast-milk was significantly higher $(P<0.02)$ than that from milk formula in group FT. The differences between groups FT and SFT, and between breast-fed, group BT and group SFT were not statistically significant. Biological availability must be higher than the relative apparent retention reported here, as part of the faecal Mn probably had been absorbed and was excreted again via bile.

Fig. 3 shows the interdependency of $\mathrm{Cu}$ intake and $\mathrm{Cu}$ retention. The values for the groups of breast-fed infants and of full-term infants given the supplemented formula were approximately normally distributed and thus the linear regression lines are given. The values for the preterm infants given supplemented milk formula fitted well to the latter group; the balances of the infants given unsupplemented formula are also shown. They also fitted to the regression line of breast-fed and supplemented-formula-fed full-term infants, as far as the regression lines are valid at these low intakes. The mean relative retention $(\%$ intake) of breast-fed infants was about 74, of supplemented-milk-fed full-term infants 52 , of supplemented-milk-fed preterm infants 46 , and of full-term infants given unsupplemented milk 23 and the corresponding preterm infants -17 and 25 in the two periods studied.

\section{DISCUSSION}

\section{Term infants}

Mn concentrations in breast-milk published during the last 20 years have been falling continuously (Iyengar, 1982). This may be partly ascribed to geographic variations (Iyengar \& Parr, 1985), but methodological aspects (prevention of contamination) are probably the main cause. Our findings for breast-milk agree well with results published recently (Stastny et al. 1984). The daily Mn intake $(1.06 \mu \mathrm{g} / \mathrm{kg})$, however, is higher than that determined by Stastny et al. (1984), $0.42 \mu \mathrm{g} / \mathrm{kg}$ for 3 month-old infants, and Vuori's (1979) calculated median values of $0.9,0.6$ and $0.5 \mu \mathrm{g} / \mathrm{kg}$ in the first, second and third months of life respectively. In previous publications higher intakes have been reported in accordance with a higher $\mathrm{Mn}$ concentration measured in milk (Vuori, 1979). Balance studies in infants have been performed by Widdowson (1969) with 1-week-old babies; Widdowson (1969) found strongly negative balances at this early age, which differ from our findings in the first collection period where four of seven balances were positive, as was the arithmetic mean. It is remarkable that from our remaining thirty-eight balances in breastfed infants at a later age, only six were negative.

$\mathrm{Mn}$ balances in formula-fed infants produced, based on a more than ten times higher intake, a higher absolute retention with both formulas. The scattering of the retention in this group can easily be explained by the excretion path of Mn. Mn homeostasis is achieved via the bile (not by renal excretion) and most of the $\mathrm{Mn}$ ingested by food is excreted unabsorbed (Mena, 1981). Thus retentions are strongly influenced by stool Mn excretion. However, the extremely high and low deviations of retention from the mean are less than the mean faecal $\mathrm{Mn}$ excretion and only one-third of the highest excretion found, which was $81.8 \mu \mathrm{g} / \mathrm{kg}$ during $72 \mathrm{~h}$.

$\mathrm{Cu}$ concentrations in breast-milk and $\mathrm{Cu}$ intakes found in our study are high compared with findings of other authors (Picciano \& Guthrie, 1976; Vaughan et al. 1979; Vuori \& Kuitunen, 1979; Rajalakshimi \& Srikantia, 1980; Ohtake et al. 1981; Higashi et al. 1982). They found mean values in the early months of lactation of about $400-600 \mu \mathrm{g} / \mathrm{l}$. Our results are comparable to those of Feely et al. (1983), who found decreasing concentrations from 939 (SD 442) $\mu \mathrm{g} / \mathrm{l}$ in the second week to 847 (SD 467) $\mu \mathrm{g} / \mathrm{l}$ in the fifth to seventh week. Consequently their calculated daily intake for newborn infants was $110 \mu \mathrm{g} / \mathrm{kg}$ and similar to ours $(115 \mu \mathrm{g} / \mathrm{kg})$. The tendency for $\mathrm{Cu}$ concentration to decrease during the course of lactation was also noted by the authors cited previously. 
Breast-fed full-term infants showed high positive balances in the first collection period caused by a high $\mathrm{Cu}$ intake. Kleinbaum (1962) and Cavell \& Widdowson (1964) found, under comparable daily intakes of $100 \mu \mathrm{g} / \mathrm{kg}$ or more, that $50 \%$ of the balances were negative. In both studies, however, the infants were somewhat younger: the infants of Cavell \& Widdowson (1964) were studied at the end of the first week and Kleinbaum (1962) studied infants in the second week of life. Our later balances from breast-fed infants were distinctly positive. No references from the literature are available to us for this time period.

Those full-term infants given the $\mathrm{Cu}$-fortified formula had, at least during the third to the fifth collection period, a similar intake (Fig. 1). Retention, however, was lower. This is expressed by the 'flatter' regression line of Fig. 3. The situation is quite different in the group given the milk formula low in $\mathrm{Cu}$ content, where most balances were slightly positive. This finding suggests the $\mathrm{Cu}$ intake from breast-milk is optimal, and indicates a lower availability of $\mathrm{Cu}$ from cow's-milk formula. The $\mathrm{Cu}$ concentration of $121 \mu \mathrm{g} / \mathrm{l}$ in our unsupplemented adapted milk formula seems suboptimal for appropriate growth.

\section{Preterm infants}

$\mathrm{Mn}$ is not accumulated prenatally in the fetal liver, as was found for $\mathrm{Cu}$ (Widdowson et al. 1972). A neonatal $\mathrm{Cu}$ deficiency in preterm infants is known, but not a $\mathrm{Mn}$ deficiency, either because deficiency symptoms are not yet known, or because the existing Mn supply is sufficient. It seems remarkable that in the first collection period of our preterm infants studied, four of six balances were negative. This finding agrees with the negative balances of 1-week-old newborn infants measured by Widdowson (1969). In neonatal mice, $\mathrm{Mn}$ homeostasis is not achieved before days 17-18 (Miller et al. 1975). The negative Mn balances of newborn infants coincide with elevated degradation of HbF-erythrocytes and a high bilirubin excretion rate (by bile?). We suspect that there is a causal connection, as the Mn content of the erythrocytes of premature infants is much higher than that in adults (Pleban et al. 1985). Continuing negative balance diminishes the body stores. Whether the Mn status of preterm infants is worse than that in full-term infants, as concluded by Friel et al. (1984) from hair analysis, cannot be decided by our study design and from our retention values in preterm infants, when no striking deviations from term infants were found.

Whereas little information is available from the literature on $\mathrm{Cu}$ balances in full-term infants, preterm infants have been more widely studied, because deficiency states (on the basis of low stores) are more likely when intake is insufficient. If the daily intake is $50-100 \mu \mathrm{g} / \mathrm{kg}$, retentions in the young newborn infants are generally negative (Kleinbaum, 1962; Dauncey et al. 1977; Mendelson et al. 1982). The deficiency decreases when newborn infants get older. Tyrala (1986) recently studied preterm newborn infants of a mean postconceptual age of 34 weeks and an average weight of $1549 \mathrm{~g}$, given formulas containing 0.9 or $2.1 \mathrm{mg} \mathrm{Cu} / 1$. Daily intakes were 121 and $294 \mu \mathrm{g} / \mathrm{kg}$, the relative retentions 9.9 and $13.4 \%$ respectively. Even under this $\mathrm{Cu}$-enriched nutrition three newborn infants of the first group and two of the second (a total of five from ten balances) were in negative balance. It may be concluded from the literature and from our few balances in preterm infants (Fig. 2) that unsupplemented milk formula is not appropriate for preterm infants in the first month of life.

\section{Influence of $\mathrm{Fe}$ on $\mathrm{Mn}$ and $\mathrm{Cu}$ resorption}

There has been controversy as to whether Fe supplementation of formula milk depresses Mn absorption (Keen et al. 1984; Stastny et al. 1984). In our two formula groups there were a few infants who received additional $\mathrm{Fe}$ medication prescribed by their family doctors. They had the same retention as those without medication, and groups FT and SFT (with 
a ten-fold Fe:Mn) also had the same mean retention. We believe that interference between $\mathrm{Fe}$ and $\mathrm{Mn}$ absorption does not occur in healthy (not Fe-depleted) infants at the concentrations of both metals found in infant formulas at the present time.

Interactions between $\mathrm{Cu}$ and $\mathrm{Zn}$ and $\mathrm{Fe}$ absorption have been discussed (Van Campen \& Scaufe, 1967; Fischer et al. 1981; Keen et al. 1984). It may be inferred that the higher concentrations of $\mathrm{Fe}$ and $\mathrm{Zn}$ in our fortified formula (Table 2), as well as therapeutical $\mathrm{Fe}$ dosages given additionally, depressed $\mathrm{Cu}$ absorption. The $\mathrm{Cu}: \mathrm{Fe}$ or $\mathrm{Cu}: \mathrm{Zn}$ value is about $0 \cdot 1$ in both formulas. Taper et al. (1980) found in female adults no differing balances when the $\mathrm{Zn}$ contents varied by a factor of 3 . In our studies absorption interactions between $\mathrm{Zn}$ and $\mathrm{Fe}$ contents of the formulas might, therefore, not be expected and in those few cases of additional $\mathrm{Fe}$ medication where interactions could be anticipated, none was observed.

\section{Relative retentions}

Availability of $\mathrm{Mn}$ and $\mathrm{Cu}$ is underestimated by balance studies, as the apparent relative retention is not necessarily correlated with the absorption, and absorbed $\mathrm{Mn}$ and $\mathrm{Cu}$ may be excreted again by bile. Nothing is known about factors like chelating agents or phytate that may influence the absorption of $\mathrm{Mn}$ and $\mathrm{Cu}$ from intestine, except that certain metals interfere with absorption. Not unexpectedly, the apparent relative retention of $\mathrm{Mn}$ (availability) was highest in breast-milk (36.7\% of intake) and lower in the formula-fed group ( 16.3 and $21.0 \%$ of intake for FT and SFT groups respectively), whereas the retained amount was lowest from breast-milk. From animal studies with a sucking rat model and ${ }^{54} \mathrm{Mn}$ extrinsic labelling, Keen et al. (1986) concluded that up to $5 \mathrm{mg} / \mathrm{l}$, a constant percentage is absorbed. They found relative retention up to $90 \%$ in 14-d-old pups. An important result of their work is an age dependency of absorption: young pups retained a higher proportion of the dose given than older pups fed on similar diets. Similarly, Mena (1981) found, at an age of $10 \mathrm{~d}$, a total body retention of $15.7 \%$ in premature children (32-34 weeks of gestation), $8 \%$ in normal newborns (full-term?) and $1-3 \%$ in adults.

Summarizing the findings of Keen et al. (1986), Mena (1981) and our own (referring to full-term infants), the apparent relative absorption (availability) of $\mathrm{Mn}$ from breast-milk and formula was similar, the intake-related daily retention was linear over a range from 1 to $15 \mu \mathrm{g} / \mathrm{kg}$ and young newborn and probably preterm infants should retain more $\mathrm{Mn}$ than older infants (Mena, 1981), although our preterm infants simultaneously had a high faecal excretion rate. Preterm infants therefore do not need more $\mathrm{Mn}$ in their formula milk than the full-term infants received in our study, namely $75-100 \mu \mathrm{g} / \mathrm{l}$. Our two formulas with $\mathrm{Mn}$ contents of 77 and $98.6 \mu \mathrm{g} / \mathrm{l}$ caused more than six times higher apparent retention in fullterm infants than in breast-fed full-term infants. Mn concentrations in milk formulas higher than $100 \mu \mathrm{g} / \mathrm{l}$ (as suggested by the National Research Council, 1980) seem unnecessary occasionally leading to an overload rather than preventing a deficiency.

From Fig. 3 it is obvious that higher $\mathrm{Cu}$ content in milk leads to a higher absolute retention. Furthermore we calculated a better relative retention of the supplemented formula compared with the unsupplemented formula, a finding which differs from that for $\mathrm{Mn}$ retention studied simultaneously in the same infants. This may be explained by a constant $\mathrm{Cu}$ excretion (loss via bile?) as suggested by the regression lines of Fig. 3 at zero intake.

The intakes of our groups BF and SFT are in full accordance with the RDAs. Considering the high availability of $\mathrm{Cu}$ from breast-milk we conclude that the $\mathrm{Cu}$ content of adapted milk formulas should be higher than in breast-milk and that this is especially important for preterm infants.

This study was supported by Milupa AG, Friedrichsdorf. The authors express their thanks to the parents and children who participated in the study. 


\section{REFERENCES}

Al-Rashid, R. A. \& Spangler, J. (1971). Neonatal copper deficiency. New England Journal of Medicine 285 , 841.843 .

Ashkenazi, A., Levin, S., Djaldetti, M., Fishel, E. \& Benvenisti, D. (1973). The syndrome of neonatal copper deficiency. Pediatrics 52, 525-533.

Beisel, W. R. (179). Metabolic balance studies - their continuing usefulness in nutritional research. American Journal of Clinical Nutrition 32, 27I-274.

Cavell, P. A. \& Widdowson, E. M. (1964). Intakes and excretions of iron, copper, and zine in the neonatal period. Archives of Diseases in Childhood 39, 496-501.

Dauncey, M. J., Shaw, J. C. L. \& Urman, J. (1977). The absorption and retention of magnesium, zinc, and copper by low birth weight infants fed pasteurized human breast milk. Pediatric Research 11, 991-997.

Doisy, E. A. Jr (1974). Effects of deficiency in manganese upon plasma levels of clotting proteins and cholesterol in man. In Trace Element Metabolism in Animals, 2, pp. 668-670 [W. G. Hoekstra, J.W. Suttic, H. E. Ganther and W. Mertz, editors]. London: Butterworths.

Dörner, K., Dziadzka, St., Oldigs, H.-D., Schulz-Lell, G. \& Schaub, J. (1985). Manganese balances in term infants. In Composition and Physiological Properties of Human Milk, pp. 117.128 [J. Schaub, editor]. Amsterdam: Elsevier.

Fecly, R. M., Eitenmiller, R. R., Jones, J. B. \& Barnhart, H. (1983). Copper, iron, and zinc contents of human milk at early stages of lactation. American Journal of Clinical Nutrition 37, 443-448.

Fischer, P., Giroux, A. \& L'Abbe, M. R. (1981). The effect of dietary zinc on intestinal copper absorption. American Journal of Clinical Nutrition 34, 1670-1675.

Friel, J. K., Gibson, R. S., Balassa, R. \& Watts, J. L. (1984). A comparison of the zinc, copper and manganese status of very low birth weight pre-term and full-term infants during the first twelve months. Acta Paediatrica Scandinavica 73, 596601 .

Graham, G. G. \& Cordano, A. (1976). Copper deficiency in human subjects. In Trace Elements in Human Health and Disease, vol. 1, pp. 363-372 [A. S. Prasad, editor]. New York: Academic Press.

Heller, R. M., Kirchner, S. G., O'Neil, J. A. Jr, Hough, A. J. Jr, Howard, L., Kramer, S. S. \& Green, H. L. (1978). Skeletal changes of copper deficiency in infants receiving prolonged total parenteral nutrition. Journal of Pediatrics 92, 947-949.

Higashi, A., Ikeda, T., Kehara, I. \& Matsuda, I. (1982). Zinc and copper contents in breast milk of Japanese women. Tohoku Journal of Experimental Medicine 137, 41-47.

Hillmann, L. S., Martin, L. \& Fiore, B. (1981). Effect of oral copper supplementation on serum copper and ceruloplasmin concentrations in premature infants. Journal of Pediatrics 98, 311-313.

Hurley, L. S. (1985). Trace elements in prenatal and neonatal development. In Trace Elements in Nutrition of Children. pp. 121-135 [R. K. Chandra, editor]. New York: Raven Press.

Iyengar, G. V. (1982). Elemental Composition of Human and Animal Milk, IAEA Report TECDOC-269. Vienna : IAEA.

Iyengar, G. V. \& Parr, R. M. (1985). Trace element concentrations in human milk from several global regions. In Composition and Physiological Properties of Human Milk, pp. 17-31 [3. Schaub, editor]. Amsterdam: Elsevier.

Keen, C. L., Bell, J. G. \& Lönnerdal, B. (1986). The effect of age on manganese uptake and retention from milk and infant formulas in rats. Journal of Nutrition 116, 395 402.

Keen, C. L., Fransson, G.-B. \& Lönnerdal, B. (1984). Supplementation of milk with iron bound to lactoferrin using weanling mice. Il. Effects on tissue manganese, zinc, and copper. Journal of Pediatric Gastroenterology and Nutrition 3, 256-261.

Kleinbaum, H. (1962). Kupferstoffwechselbilanzen bei Säuglingen. Zeitschrift für Kinderheilkunde 87, 101115.

Kotz, L., Kaiser, G., Tschöpel, P. \& Tölg, G. (1972). Aufschluß biologischer Matrices für die Bestimmung sehr niedriger Spurenelementgehalte bei begrenzter Einwaage mit Salpetersäure unter Druck in einem Teflongefäß. Zeitschrift für Analytische Chemie 260, 207-209.

Levy, Y., Zeharia, A., Grunebaum, M., Nitzau, M. \& Steinherz, R. (1985). Copper deficiency in infants fed cow's milk. Journal of Pediatrics 106, 786-788.

Mena, I. (1981). Manganese. In Disorders of Mineral Metabolism, vol. 1, pp. 233-236 [F. Brommer and J. W. Coburn, editors]. New York: Academic Press.

Mendelson, R. A., Anderson, G. H. \& Bryan, M. H. (1982). Zinc, copper and iron content of milk from mothers of preterm and full-term infants. Early Human Development 6, 145-151.

Miller, S. T., Cotzias, G. C. \& Evert, H. A. (1975). Control of tissue manganese: initial absence and sudden emergence of excretion in the neonatal mouse. American Journal of Physiology 229, 1080-1084.

National Research Council (1980). Recommended Dietary Allowances, 9th revised ed. Washington DC: National Academy of Sciences.

Naveh, Y., Hazani, A. \& Berant, M. (1981). Copper deficiency with cow”s milk diet. Pediatrics 68, 397-400.

Ohtake, M., Chiba, R., Moachizuki, K.\& Tada, K. (1981). Zinc and copper concentrations in human milk and in serum from exclusively breast-fed infants during the first 3 months of life. Tohoku Journat of Experimental Medicine 135, 335-343. 
Picciano, M. F. \& Guthrie, H. A. (1976). Copper, iron, and zinc content of mature human milk. American Journal of Clinical Nutrition 29, 242-254.

Pleban, P. A., Numerof, B. S. \& Wirth, F. H. (1985). Trace elements in the felus and neonate. Clinics in Endocrinology and Metabolism 14, 545-566.

Rajalakshimi, K. \& Srikantia, S. G. (1980). Copper, zinc, and magnesium content of breast-milk of Indian women. American Journal of Clinical Nutrition 33, 664-669.

Shaw, J. C. L. (1980). Trace elements in the fetus and young infant. II. Copper, manganease, selenium, and chromium. American Journal of Diseases of Children 134, 74-81.

Stastny, D., Vogel, R. S. \& Picciano, M. F. (1984). Manganese intake and serum manganese concentration of human milk-fed and formula-fed infants. American Journal of Clinical Nutrition 39, 872-874.

Tanaka, Y., Hatano, S., Nishi, Y. \& Usui, T. (1980). Nutritional copper deficiency in a Japanese infant on formula. Journal of Pediatrics 96, 255-257.

Taper, L. J., Hinners, M. L. \& Ritchey, S. J. (1980). Effects of zinc intake on copper balance in adult females. American Journal of Clinical Nutrition 33, 1077-1082.

Tyrala, E. E. (1986). Zinc and copper balances in preterm infants. Pediatrics 77, 513-517.

Van Campen, D. R. \& Scaufe, P. U. (1967). Zinc interference with copper absorption in rats. Journal of Nutrition 91, 473-476.

Vaughan, L. A., Weber, C. W. \& Kemberling, S. R. (1979). Longitudinal changes in the mineral content of human milk. American Journal of Clinical Nutrition 32, 2301-2306.

Vuori, E. (1979). Intake of copper, iron, manganese and zinc by healthy, exclusively breast-fed infants during the first 3 months of life. British Journal of Nutrition 42, 407-411.

Vuori, E. \& Kuitunen, P. (1979). The concentration of copper and zinc in human milk; a longitudinal study. Acta Paediatrica Scandinavica 68, 33 37.

Widdowson, E. M. (1969). Trace elements in human development. In Mineral Metabolism in Pediatrics, pp. 85-88 [D. Barltrop and W. L. Burland, editors]. Oxford: Blackwell.

Widdowson, E. M., Cahn, H., Harrison, G. E. \& Molner, R. D. G. (1972). Accumulation of Cu, Zn, $\mathrm{Mn}, \mathrm{Cr}$ and Co in the human liver before birth. Biology of the Neonate 20, 360-367. 